\title{
Intramural hematoma or aortic dissection - a diagnostic and therapeutic problem. A case report
}

\author{
Bogdan Suder, Grzegorz Wasilewski, Krzysztof Bartuś, Jerzy Sadowski, Bogusław Kapelak \\ Department of Cardiovascular Surgery and Transplantation, Jagiellonian University Medical College, John Paul II Hospital, \\ Krakow, Poland
}

Kardiochirurgia i Torakochirurgia Polska 2015; 12 (3): 238-241

\begin{abstract}
The authors present a case report of a 60-year-old patient with an ascending aortic aneurysm along with the associated diagnostic and therapeutic problems. The choice of therapy in patients with aortic intramural hematoma is difficult and should be based on comprehensive evaluation of the patient's status as well as on the experience of the radiologist and surgeon. Key words: aortic aneurysm, ascending aortic dissection.
\end{abstract}

\section{Introduction}

Acute aortic syndromes form a group of diseases that are often characterized by a very dynamic course and acute clinical signs, frequently constituting a significant threat to the patient's life. They include several nosological entities differing in terms of pathophysiology, clinical signs, and required therapeutic approach. It is essential to combine comprehensive imaging diagnostics and their careful interpretation with laboratory examinations and analysis of clinical signs.

\section{Aim of the study}

The authors present a case report of a 60-year-old patient with an ascending aortic aneurysm as well as the associated diagnostic and therapeutic problems.

\section{Material and methods}

The 60-year-old patient was referred to the Clinic of Cardiovascular Surgery and Transplantology (Medical College of the Jagiellonian University) from an Emergency Ward of a county hospital in Małopolskie Province with non-specific chest pain. The chest pain was present at rest and had lasted approximately 10 days. The patient was first hospitalized at the Emergency Ward; based on serial electrocardiography (ECG) examinations and evaluation of enzyme levels associated with myocardial injury, acute coronary

\section{Streszczenie}

W pracy zaprezentowano przypadek 60-letniego pacjenta z tętniakiem aorty wstępującej, u którego wystąpiły problemy diagnostyczne i terapeutyczne. Wybór postępowania terapeutycznego u pacjentów z krwiakiem śródściennym aorty jest trudny i powinien się opierać na całościowej ocenie stanu klinicznego chorego oraz doświadczeniu radiologa i chirurga. Słowa kluczowe: tętniak aorty, rozwarstwienie aorty wstępującej.

syndrome was excluded, and the patient was discharged home. During his next visit at the county hospital, the patient underwent computed tomography. The examination revealed the presence of an ascending aortic aneurysm (51 $\mathrm{mm}$ in the bulb, $53 \mathrm{~mm}$ in the next segment, and $38 \mathrm{~mm}$ in the arch). In the aortic bulb, the lower part of the ascending aorta, and part of the arch, a heterogeneous aortic wall was visualized - a $14 \mathrm{~mm}$ hyperdense area most likely resulting from an intramural hematoma or aortic dissection. Additionally, the examination demonstrated the presence of fluid in the pericardial sac, forming a layer up to $11 \mathrm{~mm}$ in thickness. The patient had not undergone any cardiological treatment before that time. He is a chronic smoker (40 pack-years), and has received alcoholic rehabilitation treatment.

At the time of admission to our clinic (during evening hours), the patient was in a relatively good general condition with chest pain of moderate intensity. Arterial pressure in his right arm was 130/185 $\mathrm{mmHg}$ and in the left arm 150/100 mmHg. Laboratory investigation showed no elevation in myocardial injury markers, and the level of C-reactive protein (CRP) was $26.8 \mathrm{mg} / \mathrm{l}$. Transthoracic echocardiography demonstrated no signs of aortic dissection; however, it did confirm the presence of fluid in the pericardial sac. Due to the ambiguous diagnostic results, computed tomography with contrast was repeated, and the aorta was carefully reconstructed. The examination indicated dilatation 
of the ascending aorta and aortic arch as well as signs of intramural bleeding with a thrombosed lumen extending from the aortic bulb through the ascending aorta (Fig. 1) to the outlet of the left subclavian artery (Fig. 2 and 3). Based on these results, aortic dissection could not be excluded. Additionally, a common origin of the brachiocephalic artery and the left common carotid artery was visualized in the aortic arch. Based on the clinical picture and imaging examinations, the patient was scheduled for urgent replacement of the ascending aorta.

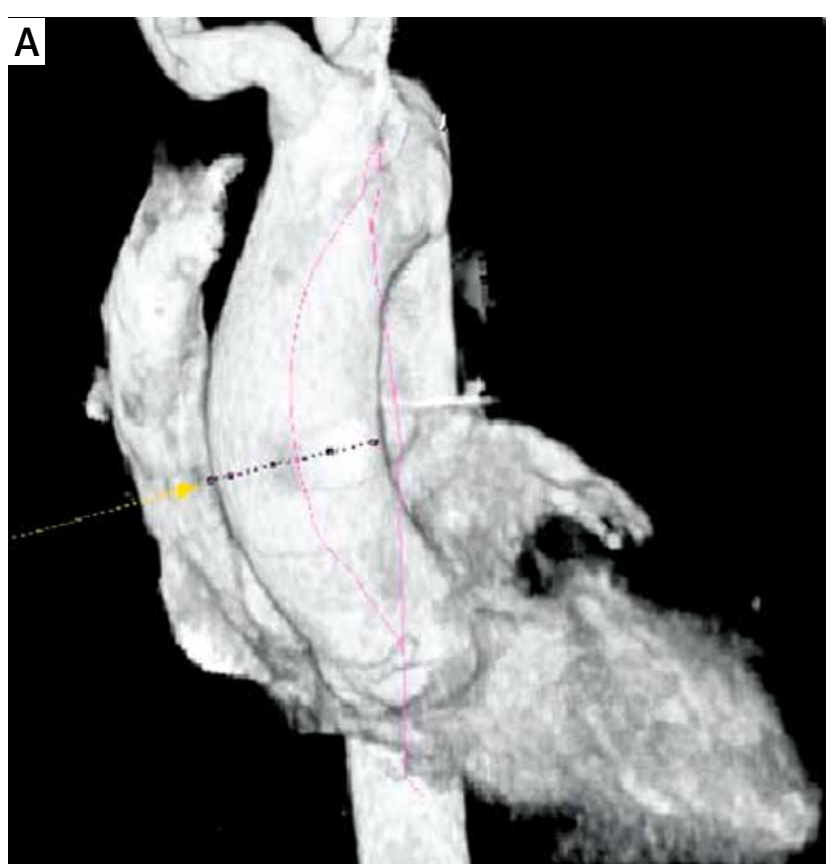

\section{Results}

The procedure was conducted in extracorporeal circulation, under deep hypothermia (up to $22^{\circ} \mathrm{C}$ ), and using cardiac protection in the form of blood cardioplegia. An aortic cannula was placed in the right common carotid artery. During the opening of the pericardial sac, cardiac tamponade was confirmed, and $300 \mathrm{ml}$ of blood was aspirated. After clamping the aorta, the aneurysmal sac was excised, and a dissection extending from the aortic bulb was visualized. Cardioplegic solution was administered. The patient's

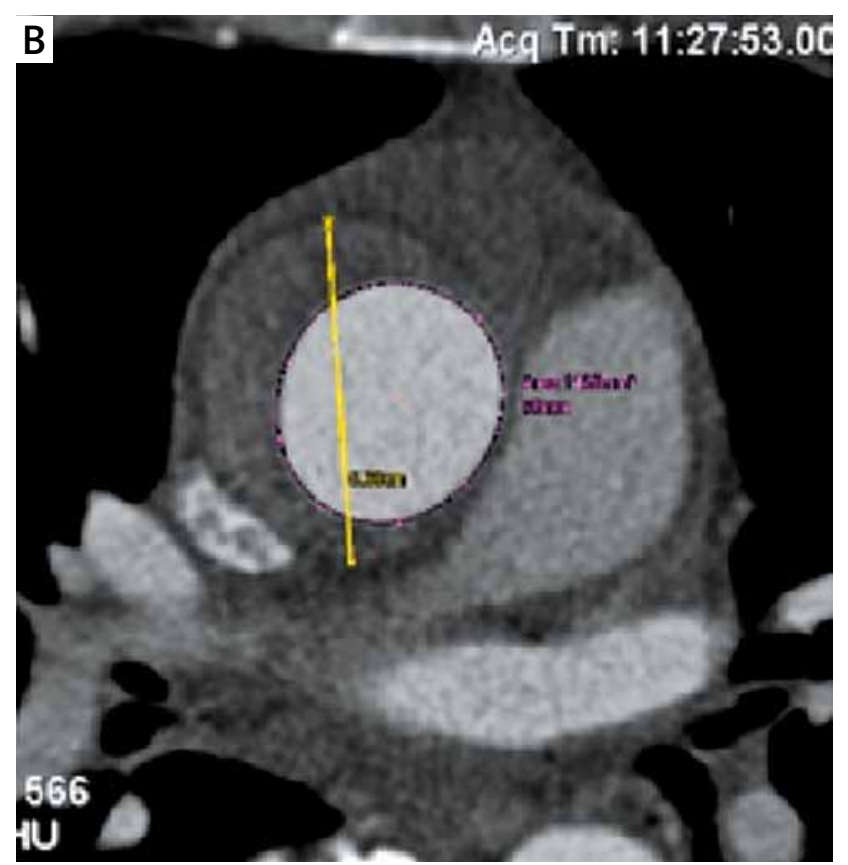

Fig. 1. Computed tomography. Aneurysmal dilatation of the ascending aorta and aortic arch, signs of intramural bleeding and thrombosed lumen
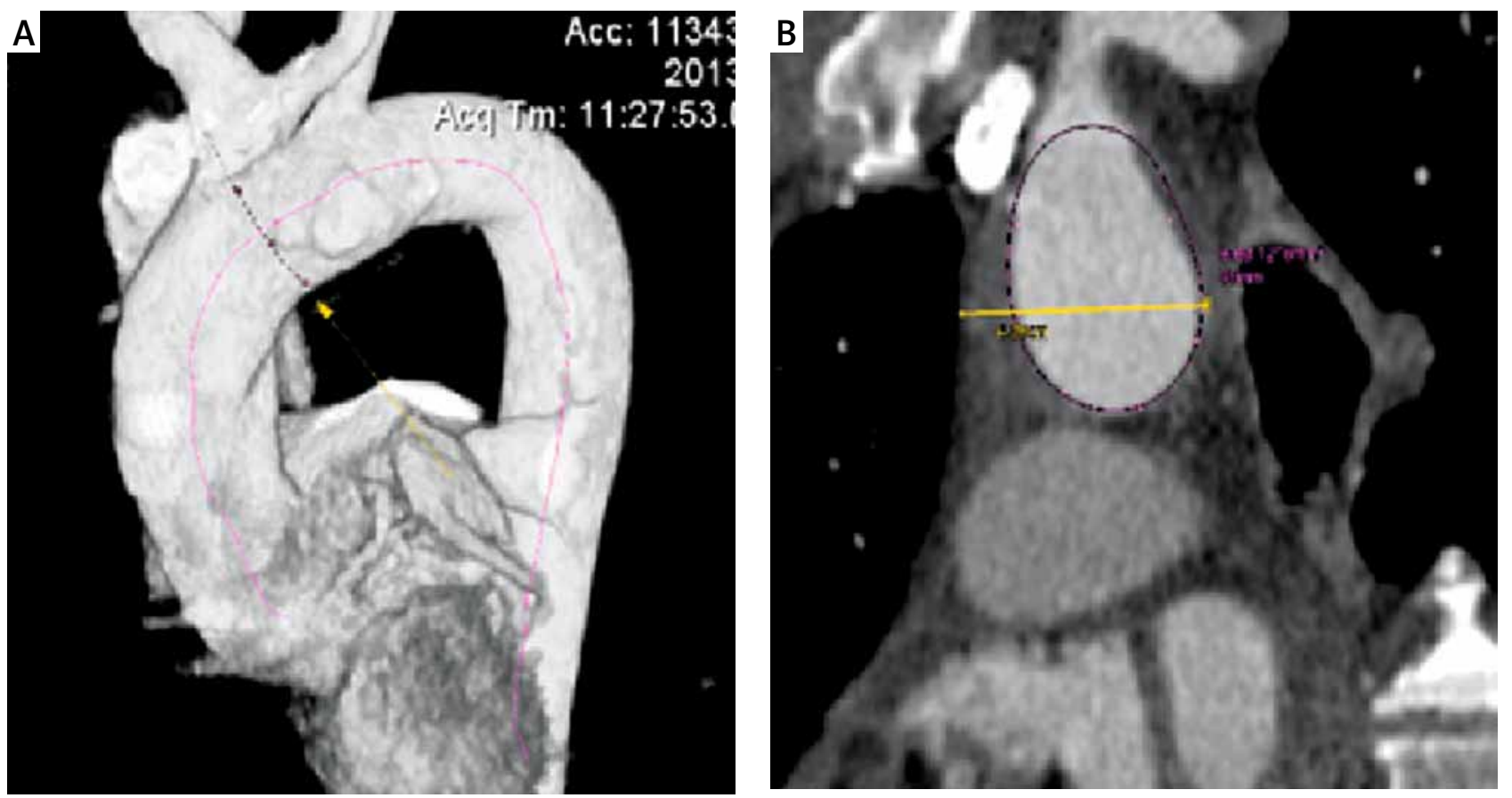

Fig. 2. Computed tomography. Thrombosed lumen extending to the outlet of the left subclavian artery 

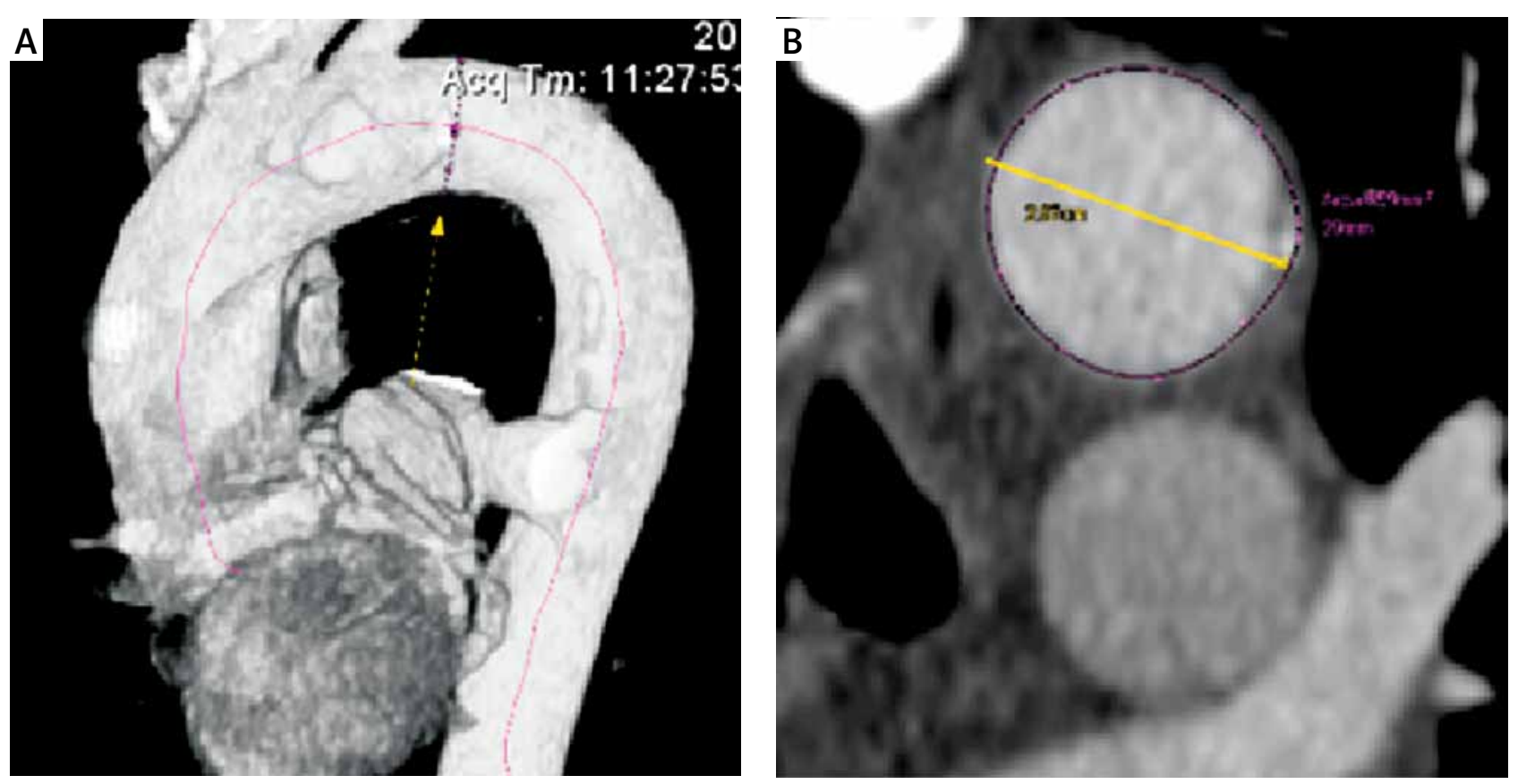

Fig. 3. Computed tomography. Thrombosed lumen extending to the outlet of the left subclavian artery

anatomy was analyzed, and a decision was made to conduct the procedure using the Bentall de Bono technique, implanting a $23 \mathrm{~mm}$ composite graft and suturing the outlet of the left coronary artery trunk end-to-side of the prosthesis. Additionally, considering the fact that the dissection involved the outlet of the right coronary artery (Fig. 4 and 5), a decision was made to create a venous coronary artery bypass to the right coronary artery (RCA). Subsequently, while conducting selective cerebral perfusion, the extent of the dissection was analyzed and a tear in the tunica intima was visualized in the vicinity of the outlet of the left subclavian artery. A decision was made to replace the aortic arch

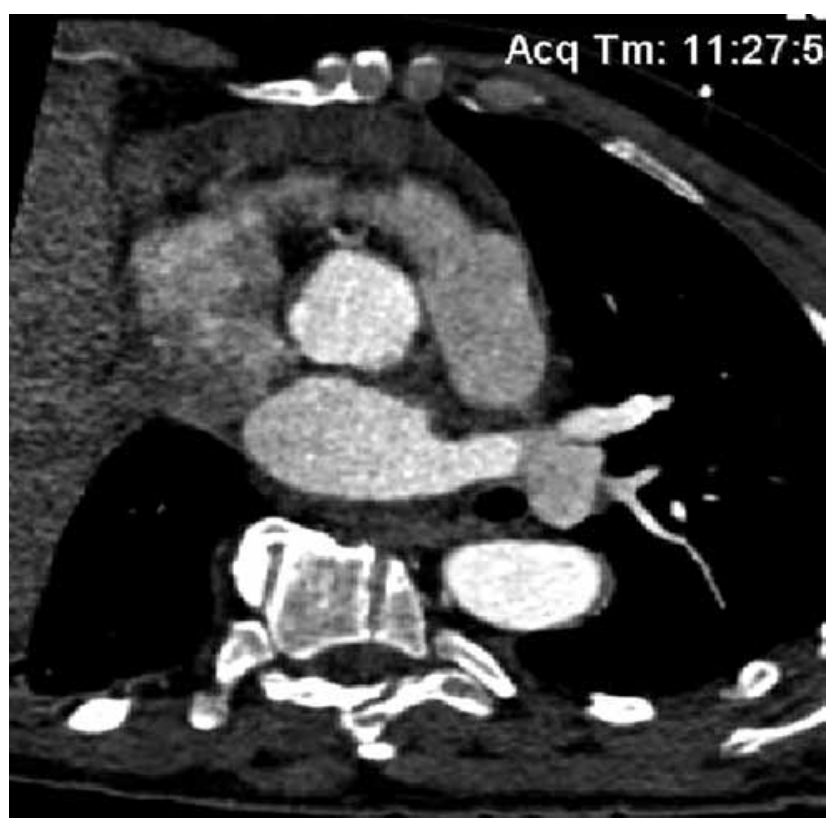

Fig. 4. Computed tomography. Dissected outlet of the right coronary artery with a straight prosthesis ( $22 \mathrm{~mm}$ in size) and suture the cephalad arteries to the prosthesis as an island.

During the $1^{\text {st }}$ postoperative day, the patient was disconnected from mechanical ventilation, and the doses of pressor agents were reduced (pressors were ultimately discontinued on the $3^{\text {rd }}$ postoperative day). The patient was transfused with 7 units of packed red blood cells, 4 units of fresh frozen plasma, and 1 unit of platelet concentrate. The subsequent postoperative course was uneventful. The patient was discharged home in good condition; further treatment was planned in a spa hospital and on an out-patient basis.

\section{Discussion}

Acute aortic syndrome (AAS) is a rapidly progressive and life-threatening disease of the aorta. The nosological

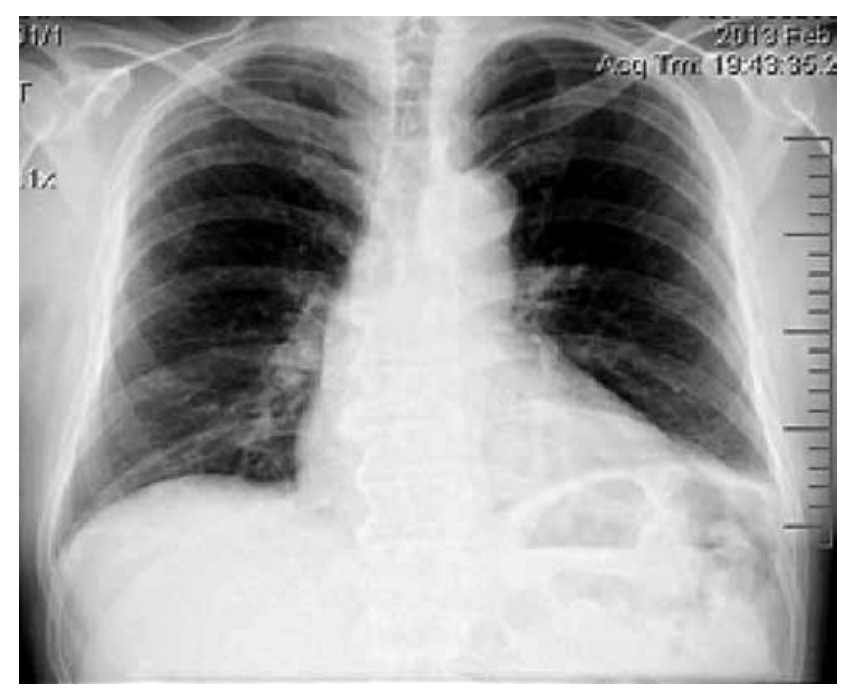

Fig. 5. Preoperative X-ray 
entities constituting AAS include aortic dissection, acute intramural hematoma $(\mathrm{AlH})$, penetrating aortic ulcer, aortic aneurysm rupture, and aortic injury [1]. On many occasions, differentiating between intramural hematoma and aortic dissection is very difficult and controversial. Some authors go as far as not to consider these nosological entities separately. Notwithstanding, precise diagnosis is of paramount importance, as these two aortic pathologies differ in terms of both the dynamics of clinical signs and the selection of treatment method. Acute intramural hematoma was first described by Krukenberg in 1920 [2]. The difference between aortic intramural hematoma and dissection is that, in the case of the former, there is no rupture of the tunica intima and no false lumen of the aorta. Intramural hematomas develop in consequence of vasa vasorum injury or the rupture of atherosclerotic plaque. Their development may be facilitated by increased arterial blood pressure or an injury. Aortic intramural hematomas constitute 10-20\% of urgent cases of aortic disease. It has been postulated on more than one occasion that some intramural hematomas have a tendency for spontaneous absorption, while others may be associated with a very significant risk of dissection or even rupture of the aortic wall; therefore, it is essential to carefully perform appropriate imaging and laboratory examinations and interpret them in conjunction with the clinical picture [3-7]. The selection of therapeutic management is often challenging and should be based on a comprehensive evaluation of the patient's clinical condition and the experience of the radiologist and the surgeon. Laboratory investigation of parameters such as D-dimer and C-reactive protein (CRP) levels can also be helpful in this context. Kitai et al. [5] suggests that patients with AlH in the form of intramural hematoma who exhibit increased values of CRP > 7.2 approximately 2 weeks after the onset of clinical symptoms are more susceptible to unfavorable events such as aortic dissection or rupture and should be treated with surgery. In a recently published study, Uzuka postulates an aggressive therapeutic approach for hemodynamically unstable patients and in cases in which the ascending aortic diameter is $>50 \mathrm{~mm}$ or the thickness of the hematoma is $>10 \mathrm{~mm}[8,9]$. In the remaining cases, it is recommended to carefully monitor the patient's condition and repeat imaging examinations in order to detect possible disease progression.

The presented patient suffered from a dissection of the ascending aorta and aortic arch (De Bakey type I, Stanford type A) with its entrance in the vicinity of the left subclavian artery, which probably developed 10 days before the surgery. Even though the imaging examinations were diagnostically ambiguous, the increased amount of fluid in the pericardial sac suggested that the patient was suffering from an aortic dissection. Other factors considered when selecting the optimal therapeutic option included the diameter of the aorta, the size of the hematoma, and the results of laboratory investigation. The option of surgical treatment was selected, consisting in the aspiration of blood from the pericardial sac and the excision of the whole aortic segment affected by the dissection. Additionally, considering the fact that the dissection extended into the outlet of the right coronary artery, a venous coronary artery bypass graft to the RCA was created.

\section{Conclusions}

The selection of therapeutic strategy for patients with aortic intramural hematomas is challenging and should be based on a comprehensive evaluation of the patient's clinical condition and the experience of the radiologist and the surgeon.

Laboratory investigation of parameters such as D-dimer and CRP levels can also be helpful in this context.

\section{Disclosure}

Authors report no conflict of interest.

\section{References}

1. Wożakowska-Kapłon B, Strączyński M. Krwiak śródścienny aorty - jedna z postaci ostrego zespołu aortalnego. Polski Przegląd Kardiologiczny 2007; 9: 437-441.

2. Krukenberg E. Beitrage zur frage des aneurysma dissecans. Beitr Pathol Anat Allg Pathol1920; 67: 329-351.

3. Chao CP, Walker TG, Kalva SP. Natural history and CT appearances of aortic intramural hematoma. Radiographics 2009; 29: 791-804.

4. Bossone E, Suzuki T, Eagle KA, Weinsaft JW. Diagnosis of acute aortic syndromes: imaging and beyond. Herz 2013; 38: 269-276.

5. Kitai T, Kaji S, Kim K, Ehara N, Tani T, Kinoshita M, Furukawa Y. Prognostic value of sustained elevated C-reactive protein levels in patients with acute aortic intramural hematoma. J Thorac Cardiovasc Surg 2014; 147: 326-331.

6. Nienaber CA. The role of imaging in acute aortic syndromes. Eur Heart J Cardiovasc Imaging 2013; 14: 15-23.

7. Hata M, Hata H, Sezai A, Yoshitake I, Wakui S, Shiono M. Optimal treatment strategy for type A acute aortic dissection with intramural hematoma. J Thorac Cardiovasc Surg 2014; 147: 307-311.

8. Uzuka T, Ito T, Hagiwara T, Yanase Y, Koyanagi T, Kurimoto Y, Kawaharada N, Higami T. A treatment strategy for early thrombosed Stanford type A acute aortic dissection. Gen Thorac Cardiovasc Surg 2013; 61: 84-88.

9. Sadowski J, Kapelak B, Bartus K, Podolec P, Rudzinski P, Myrdko T, Wierzbicki K, Dziatkowiak A. Reoperation after fresh homograft replacement 23 years' experience with 655 patients. Eur J Cardiothorac Surg 2003; 23: 996-1001. 